\title{
Hesperidin: A New Approach to Ameliorate Diazinon Induced Hepatotoxicity in Adult Male Albino Rats
}

\author{
Dalia I.A. Mesallam ${ }^{1}$, Mona Atef \\ Forensic Medicine and Clinical Toxicology, Faculty of medicine, Zagazig University, Egypt. ${ }^{1}$
}

Corresponding author:

E-mail address:

Diamaae@yahoo.com.

\section{ABSTRACT}

Diazinon (DZN) is one of the most broadly used organophosphorus insecticides in controlling agricultural pests, increasing exposure to these compounds that may have harmful side effects. Hesperidin (HN) is a citrus bioflavonoid with gifted antiinflammatory and anti-oxidant effects. The purpose of this study was to explore antioxidant and anti-inflammatory effects of HN on DZN induced hepatotoxicity in adult male albino rats. Forty-eight adult male albino rats were included into four groups; Group I served as the control (IA, IB and IC), Group II HN (50 mg/kg), Group III diazinon $(20 \mathrm{mg} / \mathrm{kg})$ and Group IV hesperidin and diazinon in doses as previously mentioned. All treatments were given daily via oral gavage for 6 weeks. Subsequently, Blood samples were collected and serum liver enzymes (ALT and AST) were determined. Then livers were extracted to assess hepatic malondialdehyde (MDA), superoxide dismutase (SOD), reduced glutathione (GSH), histopathological (Haematoxylin and Eosin staining) and immunohistochemistry using tumor necrosis factor- $\alpha(T N F-\alpha)$. Diazinon intoxication induced a significant raise of serum liver enzymes and hepatic MDA and a significant reduction in hepatic SOD and GSH. It also induced histopathological alterations in liver with strong TNF- $\alpha$ immunoreactivity. The previous toxic effects were partially improved by hesperidin treatment in combination with DZN. It can be concluded that HN supplementation alleviates DZN induced hepatotoxicity via antioxidant and anti-inflammatory properties.

Key words: Diazinon, Hesperidin, Hepatotoxicity, Oxidative stress, Tumor necrosis factor- $\alpha$.

\section{INTRODUCTION}

O rganophosphates pesticides are universally used as insecticides. They are generally the furthermost toxic pesticides for animal species particularly vertebrate animals (Shah and Iqbal, 2010).

Diazinon is a frequently used organophosphorus (OP) pesticide (diethoxy[(2-isoprophyl- 6-methyl-4-pyrimidinyl) oxy] thioxophosphorane) and widely used in agricultural practices and parasitic infestations in animals (Sarabia et al., 2009 and Wang et al., 2017).

Although these valuable uses, extensive DZN exposure may be harmful to animals and humans. Human exposure to DZN can occur via inhalation, ingestion and/or dermal exposure (Mehanny et al., 2015). Acute DZN toxicity is accompanying with increased secretions, seizures, and ultimately paralysis of respiratory muscle. While chronic contact is accompanying with disruption of endocrine system, teratogenicity and carcinogenicity (Larkin and Tjeerdema, 2000).

Hindering the acetylcholinesterase (AChE) enzyme activity considered as the main mechanism of DZN toxicity, that resulting in excess stimulation of cholinergic receptors and neurotoxicity (Slotkin et al., 2019).

Previous studies have found that DZN can produce widespread toxic effects in the cardiovascular, genitourinary, and nervous systems. This toxic effect has been endorsed to oxidative stress (through inducing reactive oxygen species production and decreasing the activities of antioxidant enzymes), DNA disruption and pro-inflammatory activities (Abdel-Daim et al., 2018 and Danaei et al., 2019). 
Hence, using of free radical scavengers and antioxidants can moderate the oxidative stress and lipid peroxidation associated with organophosphorus toxicity (Cemek et al., 2010).

Hesperidin, a citrus bioflavonoid, has a promising anti-oxidant, anti-inflammatory, lipid lowering, anti-cancer, neuro-protective and glucose lowering effects. Numerous studies have stated that the $\mathrm{HN}$ anti-inflammatory effects are arbitrated by numerous mechanisms that including deactivation of both nitric oxide synthases and cyclooxygenases, and inhibition of inflammatory cytokines and suppression of hypoxia inducible factor-1 alpha (Lee et al., 2012).

Hesperidin has also anti-oxidant effects, which credited to free radical washing activity, ROS neutralization and increasing of cellular anti-oxidant defenses (Parihz et al., 2015). Therefore, this study aimed to assess effects of $\mathrm{HN}$ on DZN induced hepatotoxicity in adult male albino rat.

\section{Materials and methods}

\subsection{Materials:}

Diazinon (99\% purity, CAS No. 333-41-5), soluble in petroleum or corn oil. It was colorless oil with very offensive odor. It was produced by Sigma--Aldrich Company, Louis St., USA and obtained from Sigma-Egypt.

Hesperidin: ( $\geq 80 \%$ purity powder, CAS No. 520-26-3) was produced by Sigma-Aldrich Company., Saint Louis, USA and obtained from Sigma-Egypt.

\subsection{Animals and grouping}

All rats' experiments were achieved in agreement with the applicable rules and valid guidelines of the faculty of Medicine, Zagazig University, Egypt, which are in agreement with the National Institutes of Health Guidelines for Animal Care. A total number of 48 adult male albino rats (weighing 150-175 g) were bred and raised at the center of animal care. Rats were acclimatized for 15 days under typical laboratory conditions before beginning of experiment. Food and water were through existing ad libitum. Room temperature was kept at $22 \pm 3{ }^{\circ} \mathrm{C}$, twelve hours dark - light cycles, with $40-60 \%$ humidity. Animals were randomly allocated to one of 4 groups:

Group I (control group): consisted of 3 groups each of 8 rats:

- Group IA (negative control group):

Rats received only regular food and water with no medication given to assess the basic parameters for 6 weeks.

- Group IB (positive control group):

Each rat was orally gavaged by $1 \mathrm{ml}$ of corn oil once daily (diazinon solvent) for 6 weeks.

- Group IC (Positive control group):

Each rat was orally gavaged by $1 \mathrm{ml}$ of $0.9 \%$ $\mathrm{NaCl}$ saline once daily (Hesperidin solvent) for 6 weeks.

\section{Group II (HN group):}

Each rat was orally gavaged by $\mathrm{HN}$ (50 $\mathrm{mg} / \mathrm{kg}$ ) dissolved in $0.9 \% \mathrm{NaCl}$ saline once daily for 6 weeks (Merzoug and Toumi, 2017).

\section{Group III (DZN group):}

Each rat was orally gavaged by DZN at a dose of $20 \mathrm{mg} / \mathrm{kg}$ dissolved in corn oil once daily for 6 weeks. This dose represents $1 / 20$ of oral $\mathrm{LD}_{50}$ of $\mathrm{DZN}$ in rats $(400 \mathrm{mg} / \mathrm{kg})$ (Gokcimen et al., 2006).

\section{Group IV (DZN \& HN group):}

Each rat was orally gavaged by both HP and DZN at the same previous doses once daily for 6 weeks.

\subsection{Specimen collection:}

2.3.1 Blood Samples: 24 hours after the last treatment, all rats were given anesthesia by ether and by using a capillary glass tube obtain a venous blood sample $(3 \mathrm{~mL})$ from the retroorbital plexus. Then, ejected the samples into glass tubes (non-heparinized) and permitted to form a clot for $30 \mathrm{~min}$, then the serum was separated by centrifugation $(600 \times \mathrm{g} 15 \mathrm{~min}, 4$ 
${ }^{\circ} \mathrm{C}$ ) and kept at $-20{ }^{\circ} \mathrm{C}$ until investigation (Nemzek et al., 2001).

2.3.2 Organs. Rats were sacrificed by cervical dislocation. Livers of all rats were extracted, washed using saline (ice cold) and weighed. Then, one half of liver was homogenized for MDA, SOD and GSH analysis. Fixation of the other half was in $10 \%$ formalin for histopathological and immunohistochemical studies.

\subsection{Biochemical studies}

2.4.1 Liver enzymes: Serum AST and ALT were analyzed using the spectrophotometric method of Murray (1984) and Reitman and Frankel (1957) respectively.

2.4.2 Hepatic Malondialdehyde (MDA) level: was analyzed using the spectrophotometric method of Ohkawa et al. (1979).

2.4.3 Hepatic superoxide dismutase (SOD): was spectrophotometrically assayed using the method defined by Nagi et al. (1995). Which depend on the SOD-mediated hang-up in the rate of nitroblue tetrazolium lessening to the blue formazan (at alkaline $\mathrm{pH}$ ).

2.4.4 Hepatic reduced glutathione (GSH): was spectrophotometrically assayed at $405 \mathrm{~nm}$ using the method defined by Shaik and Mahvar (2006).

All above kits are purchased from bio diagnostic chemical company, Egypt.

\subsection{Histopathology}

2.5.1 Haematoxylin and Eosin staining $(\mathrm{H} \&$

E): Paraffin blocks were partitioned at a $5 \mu \mathrm{m}$ thickness and undergo staining with $\mathrm{H} \& \mathrm{E}$ according to Bancroft and Stevens (1996). Then Sections were de-waxed with xylene, rehydrated by alcohol (descending grades) $(100 \%, 96 \%$, and $70 \%)$, formerly hematoxylin staining for $20 \mathrm{~min}$ and eosin staining for 10 min and studied using light microscopy.

\subsubsection{Immunohistochemical examination:} was done to liver specimens from all groups with labeled streptavidin-biotin (LSAB) technique which is a more sensitive method. The sections were deparaffinized and incubated in hydrogen peroxide to suppress the endogenous peroxidase. Then, the sections were incubated with the tumor necrosis factor alpha (TNF- $\alpha$ ) primary antibodies. It was detected by using the TNF- $\alpha$ rabbit polyclonal primary antibody. Then, the sections were incubated with peroxidase labeled streptavidin and the secondary antirabbit antibodies. Formerly, incubation with substrate chromogenic was done to complete the staining that resulted in formation of precipitate at the antigen sites that has a brown-color. Mayer's haematoxylin was used as a counter stain (Bancroft \& Cook, 1994 and Bhan, 1995).

2.6. Statistical analysis. Data were studied by Statistical Package of Social Science (SPSS), software version 20. Quantitative data were summarized as mean $\pm \mathrm{SD}$ (standard deviation). Comparison of several means were done by One Way Analysis of Variance (ANOVA), followed by Least Significance Difference test "LSD" for multiple comparisons between groups. Pearson's Correlation co-efficient rank test; it was used to rank different variables against each other in linear correlation which may be positive or negative. Probability ( $P$ value of $>0.05$ indicates non-significant results; $\mathrm{P}$ value $<0.05$ means significant difference, $\mathrm{p}<0.001$ for highly significant result).

\section{Results}

\subsection{Biochemical results}

There was no statistically significant difference observed between different subgroups of control group (IA, IB, IC) regarding the biochemical parameters (ALT, AST, MDA, SOD \& GSH). So, the negative control group (IA) was used as a control group for comparison with other treated groups.

3.1.1 Liver function tests. Serum ALT and AST levels in control group and hesperidin group exhibited no statistically significant differences $(\mathrm{p}>0.05)$. Diazinon intoxicated group showed a highly significant $(\mathrm{p}<0.001)$ upsurge in mean values of ALT and AST compared to control group. Co-treatment of hesperidin with DZN resulted in a highly significant $(\mathrm{p}<0.001)$ diminution in ALT and 
AST mean values in comparison to DZN alone. However, their levels are quite higher significantly $(\mathrm{p}<0.001)$ than control group (Table 1).

3.1.2 Oxidative Stress Markers in hepatic tissue: MDA, SOD and GSH levels in the control group and the hesperidin treated group exhibited no statistically significant differences $(p>0.05)$. Diazinon intoxicated group revealed a highly significant $(p<0.001)$ rise in mean values of hepatic MDA and a highly significant $(p<0.001)$ decrease in mean values of hepatic SOD and GSH compared to control group. Coadministration of hesperidin with DZN resulted in a highly significant $(\mathrm{p}<0.001)$ diminution in mean values of hepatic MDA and a highly significant $(\mathrm{p}<0.001)$ increase in mean values of hepatic SOD and GSH compared to DZN alone. Moreover, hepatic GSH exhibited nonsignificant $(\mathrm{p}>0.05)$ difference, while SOD levels are still significantly $(\mathrm{p}<0.001)$ lower and MDA levels are quite higher significantly $(\mathrm{p}<0.001)$ than control group (Table 2).

3.1.3 Correlation of Serum ALT and AST with hepatic Oxidative Stress Markers: Serum ALT and AST levels exhibited a highly negative significant $(\mathrm{p}<0.001)$ correlation with SOD and GSH levels and a highly positive significant $(\mathrm{p}<0.001)$ correlation with MDA level (Table 3).

Table (1): Statistical comparison among different groups of study as regard liver enzymes levels by ANOVA test.

\begin{tabular}{|l|l|l|l|l|c|c|}
\hline Parameters & $\begin{array}{l}\text {-ve } \\
\text { Control }\end{array}$ & Hesperidin & Diazinon & $\begin{array}{l}\text { Hesperidin\& } \\
\text { Diazinon }\end{array}$ & $\mathrm{F}$ & $\mathrm{P}$ \\
\hline ALT(IU/L) & $24.5 \pm 1.7$ & $24.3 \pm 2.96 \#$ & $75.8 \pm 3.7^{\mathrm{a}}$ & $36.3 \pm 3.8^{\mathrm{ab}}$ & 484.26 & $<0.001^{* *}$ \\
\hline AST (IU/L) & $30.6 \pm 2.3$ & $29.9 \pm 1.9 \#$ & $88.9 \pm 5.8^{\mathrm{a}}$ & $44.9 \pm 1.5^{\mathrm{ab}}$ & 548.35 & $<0.001^{* *}$ \\
\hline
\end{tabular}

$\mathrm{n}=8$ in each group; (Mean $\pm \mathrm{SD})$

${ }^{\#} \mathrm{p}>0.05,{ }^{\mathrm{a}} \mathrm{p}<0.001$ compared to - ve control group; ${ }^{\mathrm{b}} \mathrm{p}<0.001$ compared to diazinon group

SD: Standard deviation; ALT: Alanine transferase; AST: Aspartate transferase

Table (2): Statistical comparison among different groups of the study as regard hepatic MDA, SOD \& GSH by ANOVA test.

\begin{tabular}{|c|c|c|c|c|c|c|}
\hline Parameters & -ve control & Hesperidin & Diazinon & $\begin{array}{c}\text { Hesperidin\& } \\
\text { Diazinon }\end{array}$ & $\mathrm{F}$ & $\mathrm{P}$ \\
\hline $\begin{array}{c}\text { MDA } \\
(\mathrm{nmol} / \mathrm{g} \text { tissue })\end{array}$ & $45.4 \pm 3.94$ & $44.7 \pm 3.4 \#$ & $126.8 \pm 8.7^{\mathrm{a}}$ & $4.5 \pm 4.6^{\mathrm{ab}}$ & 382.708 & $<0.001^{* *}$ \\
\hline $\begin{array}{c}\text { SOD } \\
(\mu / \mathrm{mg} \text { protein })\end{array}$ & $38.5 \pm 2.6$ & $39.8 \pm 3.4 \#$ & $14.9 \pm 3.7^{\mathrm{a}}$ & $27.4 \pm 3.96^{\mathrm{ab}}$ & 46.642 & $<0.001^{* *}$ \\
\hline $\begin{array}{c}\text { GSH (mmol/g } \\
\text { tissue })\end{array}$ & $8.1 \pm 0.9$ & $8.5 \pm 0.9 \#$ & $3 \pm 1.04^{\mathrm{a}}$ & $7.6 \pm 1.4^{\mathrm{\# b}}$ & 90.003 & $<0.001^{* *}$ \\
\hline
\end{tabular}

$(\mathrm{n}=8$ in each group) (Mean $\pm \mathrm{SD})$

${ }^{\#} \mathrm{p}>0.05,{ }^{\mathrm{a}} \mathrm{p}<0.001$ compared to control group; ${ }^{\mathrm{b}} \mathrm{p}<0.001$ compared to diazinon group

SD: Standard deviation; MDA: Malondialdehyde; SOD: Superoxide dismutase; GSH: Reduced glutathione 
Table (3): Correlation of serum ALT and AST with hepatic oxidative stress markers

\begin{tabular}{|c|c|c|c|c|c|c|}
\hline \multirow{2}{*}{ Parameters } & \multicolumn{2}{|c|}{ MDA } & \multicolumn{2}{c|}{ SOD } & \multicolumn{2}{c|}{ GSH } \\
\cline { 2 - 7 } & $(\mathrm{r})$ & $\mathrm{p}$ & $(\mathrm{r})$ & $\mathrm{P}$ & $(\mathrm{r})$ & $\mathrm{p}$ \\
\hline ALT & 0.964 & $<0.001 * *$ & -0.899 & $<0.001 * *$ & -0.903 & $<0.001^{* *}$ \\
\hline AST & 0.965 & $<0.001 * *$ & -0.910 & $<0.001 * *$ & -0.904 & $<0.001 * *$ \\
\hline
\end{tabular}

r: correlation coefficient. $* *$ : highly significant $(\mathrm{p}<0.001)$.

ALT: Alanine transferase; AST: Aspartate transferase; MDA: Malondialdehyde; SOD: Superoxide dismutase;

GSH: Reduced glutathione

\subsection{Histopathology}

3.2.1 Haematoxylin and eosin staining. Examination of H\&E stained hepatic sections of control group revealed normal lobular hepatic architecture; the pentagonal or hexagonal lobules with central veins and portal areas (peripheral hepatic triads) consisted of connective tissue stroma that contained branches of portal veins, hepatic artery, and bile duct. Hepatocytes are arranged in cords running radially from the central vein. They had stippled form of the acidophilic cytoplasm and had large pale vesicular nuclei. These cords were parted by narrow sinusoidal spaces (Fig. 1 A \& B). Histopathological examination of liver from DZN treated group showed marked congestion of the central vein and sinusoids, some hepatocytes with pyknotic nuclei and intracytoplasmic vacuolation (apoptotic cells), dilated bile duct, hyalinization and thickening of the arterial wall and mononuclear inflammatory cells infiltration (Fig. 1C \& D).
Co-administration of $\mathrm{HN}$ with DZN caused obvious improvement indicated by mild dilatation and congestion of the central vein and sinusoids, mildly dilated bile duct and hyalinization of the arterial wall, and most hepatocytes were polyhedral with acidophilic cytoplasm and rounded vesicular nuclei (Fig. $1 E \&$ F).

3.2.2 Immunohistochemical results (light microscopic detection of TNF- $\alpha$ ). The liver sections of control group showed negative TNF$\alpha$ immunoreactivity in the cytoplasm of hepatocytes (Fig. 2A). DZN treated group showed strong positive TNF- $\alpha$ immunoreactivity in the cytoplasm of hepatocytes compared to control group (Fig. 2B). On the other hand, HN treatment with DZN revealed weak positive TNF- $\alpha$ immunoreactivity in the cytoplasm of hepatocytes compared to DZN alone (Fig. 2C). 

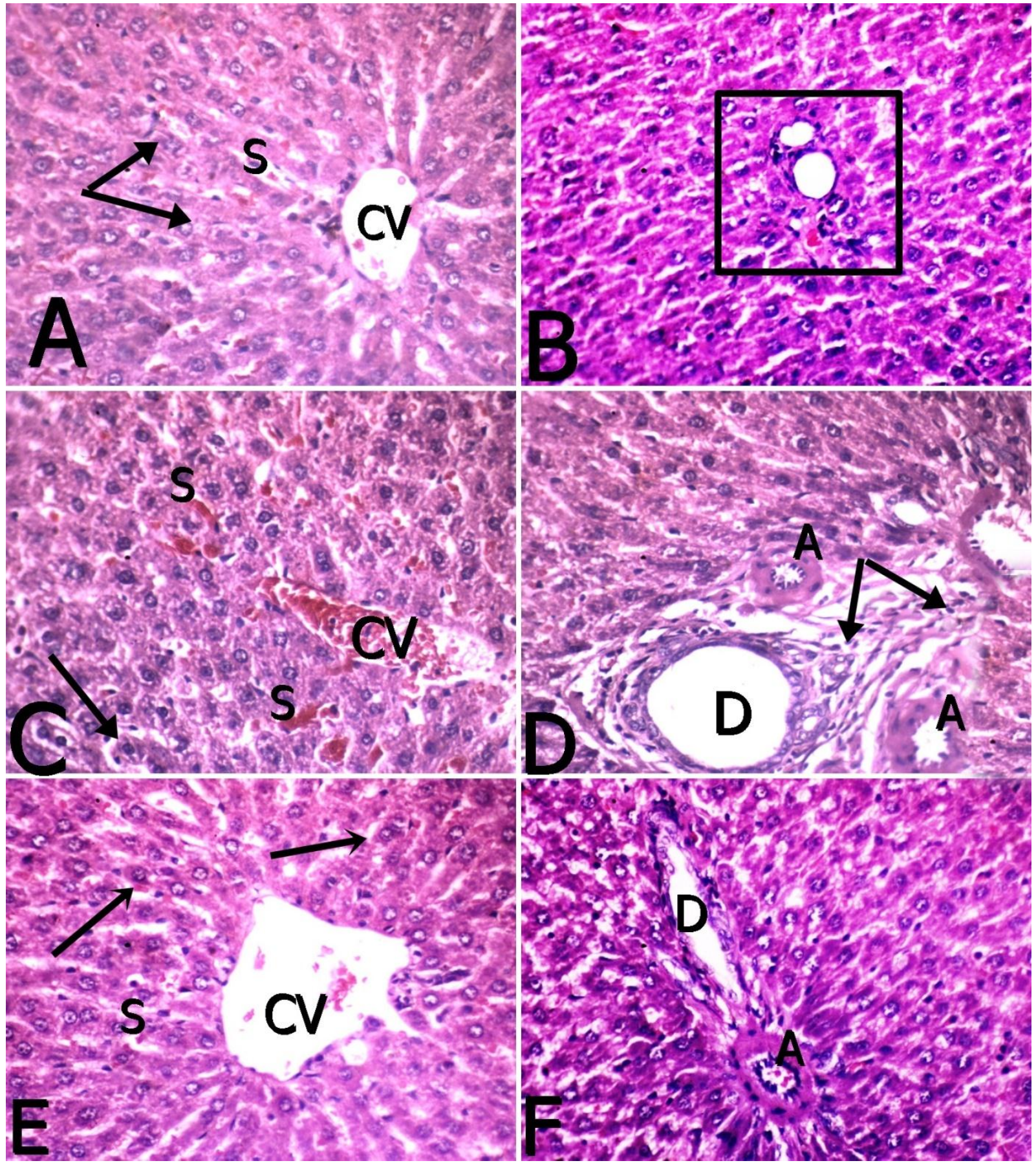

Fig. (1): photomicrographs of liver section in adult male albino rats. (A \& B) control group showing normal lobular architecture; $\mathrm{CV}=\mathrm{Central}$ vein, $\mathrm{S}=$ blood sinusoids, arrow= hepatocytes are polyhedral with acidophilic cytoplasm and round vesicular nuclei, black box= portal area. (C \& D) DZN group (20 $\mathrm{mg} / \mathrm{kg} /$ day) for 6 weeks, arrow= hepatocytes with pyknotic nuclei and intracytoplasmic vacuolation, $\mathrm{CV}=$ marked congested central vein, $\mathrm{S}=$ congested sinusoids, double arrow $=$ mononuclear inflammatory cells, $\mathrm{D}=$ dilated bile ducts and $\mathrm{A}=$ hyalinization and thickening of the arterial wall. (E \& F) $\mathrm{HN}+\mathrm{DZN}$ group showing nearly normal lobular architecture (H \& E X400). 



Fig. (2): Photomicrographs of immunohistochemical staining of TNF- $\alpha$ in the livers of adult male albino rats. (A) Control group showing negative TNF- $\alpha$ immunoreactivity in cytoplasm of hepatocytes (arrow). (B) DZN group (20 mg/kg/day) for 6weeks showing strong positive TNF- $\alpha$ immunoreactivity in cytoplasm of hepatocytes (arrow). (C) HN+DZN group showing weak positive TNF- $\alpha$ immunoreactivity in cytoplasm of hepatocytes (arrow) (Immunohistochemical x400).

\section{Discussion}

The liver could be an exceptionally pivotal organ for the detoxification processes and the main location of DZN metabolism, by assembling a large amount of its metabolites (Beydilli et al., 2015).

Hesperidin is an active flavonoid found in citrus fruits possessing antioxidant and antiinflammatory actions ( $\mathbf{L i}$ and Schluesener, 2017). To our knowledge, it is the first time to examine the protecting effects of hesperidin on DZN induced hepatotoxicity in adult male albino rats.

The current study showed that the oral administration of DZN in male rats at a dose of $20 \mathrm{mg} / \mathrm{kg}$ body weight for 6 weeks induced hepatotoxic, oxidative stress and inflammatory effects. While, Co-administration of $\mathrm{HN}$ with DZN resulted in partial improvement as regard previous toxic effects.

In the present study, DZN exposure induced hepatotoxic effect as reflected by a highly significant $(\mathrm{p}<0.001)$ rise in ALT and AST levels in comparison with control group. These were in line with Hariri et al. (2010), Sarhan and Al-Sahhaf (2011), Beydilli et al. (2015), Yousefizadeh et al. (2019) and AbdelDaim et al. (2020) who found a significant increase in serum liver enzymes regardless species, dose and duration of treatment with DZN.

Oxidative hepatic damage of DZN was indicated in the present study by a highly significant $(p<0.001)$ increase in liver MDA 
level and a highly significant $(\mathrm{p}<0.001)$ decrease in liver SOD and GSH levels compared to control group. These findings were in line with previous studies suggesting that one of the molecular mechanisms of DZN induced hepatotoxicity was regulated through ROS generation and oxidative mechanism (ElShenawy et al., 2010; Hariri et al., 2010; Lari et al., 2015; Mehanny et al., 2015; Karimani et al., 2018 and Abdel-Daim et al., 2020).

MDA induction seen in this study was in line with some studies previously published (Altuntas et al., 2004; Amirkabirian et al., 2007; Shah and Iqbal, 2010 and Jafari et al., 2012). They reported increased lipid peroxidation in rats exposed to DZN. High lipid peroxidation may be due to the oxidation of molecular oxygen to produce superoxide radicals, this reaction is also the source of hydrogen peroxide, which produces MDA by triggering the peroxidation of unsaturated fatty acids in the membrane, resulting in organ injury due to the effects on membrane function, inactivation of membrane receptors and enzymes, and increased tissue permeability (Rahman, 2005 and Karimani et al., 2018).

Regarding levels of SOD and GSH, the results of present study were supported by ElShenawy et al. (2010), Mehanny et al. (2015) and Abdel-Daim et al. (2020), who found that DZN-treatment decreases the activity of antioxidant enzymes SOD, CAT, GPx and GST and level of GSH. Other oxidative effects of DZN include augmenting the activity of NADPH oxidase and inducible nitric oxide synthase and inhibiting the activity of glutathione reductase (Shah and Iqbal 2010; Pakzad et al. 2013 and Ogasawara et al. 2017).

Enzymatic and non-enzymatic antioxidants work together to inhibit the effect of ROS in tissues and have a role in the defense against oxidative cellular damage by free radical scavenging (Abdollahi et al., 2004).

Therefore, SOD, CAT and GPx are considered first defensive lines that preserve cellular elements from oxidative injury. For example, SOD promotes conversion of superoxide anion into less reactive particles $(\mathrm{H} 2 \mathrm{O} 2)$ which is rapidly changed to water and oxygen by CAT and GPx (Peixoto et al., 2004 and Sharma and Sangha, 2014).

The decrease in SOD level in the hepatocytes of rats exposed to pesticides may be due to over manufacture of $\mathrm{O} 2 \cdot-$ which rapidly changed to $\mathrm{H} 2 \mathrm{O} 2$ by SOD (Mossa et al., 2015). In a previous study, the GSH levels in rat red blood cells were significantly decreased after drug injection in comparison with the control group. The reduction in GSH level could be due to over use of GSH in the non-enzymatic washing of oxygen radicals. Furthermore, GSH decreases peroxides and preserves protein thiols in the reduced form (Anandan and Subramanian, 2012).

Beydilli et al. (2015) attributed the injurious mechanism of DZN to increasing myeloperoxidase (MPO) and nitric oxide (NO) levels that have a role in pathogenesis of hepatic damage via oxidative stress mechanism.

Also, Abdel-Daim et al. (2020) explained the increased liver enzymes in rats treated with DZN by oxidative stress-mediated increase in liver cells permeability, leading to leakage of liver enzymes to the blood stream. This confirms the results of present study as evidenced by that serum ALT and AST levels showed a negative highly significant $(\mathrm{p}<0.001)$ correlation with liver SOD and GSH levels and a positive highly significant $(\mathrm{p}<0.001)$ correlation with liver MDA level.

The results of present study showed that co-administration of $\mathrm{HN}$ with DZN significantly increased liver GSH and SOD level and decreased liver MDA, suggesting antioxidant properties of $\mathrm{HN}$ as a protective agent. These results were supported by that of Tirkey et al. (2005), Anandan and Subramanian (2012), Abdallah et al. (2013), Pari et al. (2015), Çetin et al. (2016), Nathiya et al. (2016) and Rabee and Bennasir (2018).

It has been suggested that antioxidant activities of flavonoids are due to their hydrogen-donating and free-radical scavenging 
properties. Flavonoids can inhibit free radical formation and the propagation of free radical reactions through the chelation of metal ions. The free-radical scavenging activity of HN may be attributed to the presence of 3'hydroxy and the 4'methoxy group on the aromatic B ring, which donates hydrogen and an electron to neutralize the hydroxyl and superoxide free radicals (Anandan and Subramanian, 2012).

Moreover, Tirkey et al. (2005) mentioned that treatment with $\mathrm{HN}(200 \mathrm{mg} / \mathrm{kg})$ was able to show improvement in the levels of endogenous antioxidant enzymes (SOD and catalase) and GSH in liver of $\mathrm{CCl} 4$ treated rats. It has been reported to act as a strong consumer of superoxide, singlet oxygen and hydroxyl radicals, thereby contributing significantly to the intracellular antioxidant defense system.

Hepatoprotective effect of $\mathrm{HN}$ was attributed to its ability to enhance glutathione production by providing more substrate for reactive intermediates that promote the detoxification mechanisms. This might be the reason for the restoration of other antioxidant enzymes such as superoxide dismutase, catalase and glutathione peroxidase (Abdallah et al., 2013).

The biochemical findings in the present study were supported by histopathological changes in the form of marked congestion of the central vein and sinusoids, some apoptotic hepatocytes (pyknotic nuclei and intracytoplasmic vacuolation), dilated bile duct, hyalinization and thickening of the arterial wall and mononuclear inflammatory cells infiltration.

The histopathological results of current study were similar to that of Al-Attar (2015), Mehanny et al. (2015), Ezzi et al. (2016) and Ahmadi et al. (2019) who showed that rats treated with DZN had many severe histopathological alterations including hepatocyte vacuolization, mononuclear cell infiltration, activated Kupffer cells, venous congestion, sinusoidal dilatation and disruption of the radial alignment of hepatocytes around the central vein. Cytoplasmic vacuoles develop due to buildup of ions and water in cytosol and rapidly pass through leaky membranes of cell organelles. Massive buildup of fluids in the vacuoles may finally lead to cell degeneration (Sarhan and Al-Sahhaf, 2011).

Kalender et al. (2005) reported that long-term intoxication with diazinon $(10 \mathrm{mg} / \mathrm{kg}$ for 7 weeks) produced swelling of mitochondria and breaking up of the mitochondrial cristae of liver cells in DZN intoxicated groups with electron microscopy.

In another study, Lari et al. (2015) found that DZN produces apoptosis in the liver cells through induction of caspases-9 and -3 . Moreover, DZN exposure significantly induced Bax/Bcl-2 ratio by $25 \%$.

Co-administration of $\mathrm{HN}$ with DZN resulted in partial improvement in hepatic damage as evidenced by a highly significant ( $\mathrm{p}$ $<0.001)$ reduction in mean values of ALT and AST in comparison with DZN alone. Also, there was obvious improvement in histopathological changes in the liver. These results passed in parallel with those of Tirkey et al. (2005), Abdallah et al. (2013), Pari et al. (2015), Çetin et al. (2016) and Rabee and Bennasir (2018) who implied that $\mathrm{HN}$ inhibits hepatic damage, prevent enzymes leakage through cellular membrane, protect the plasma membranes integrity and restore levels of these enzyme.

Moreover, Anandan and Subramanian (2012) reported that HN treatment produced complete reversal of gentamycin induced tubular necrosis by increasing the cellular antioxidants. In addition, treatment with $\mathrm{HN}$ (20, 40 and $80 \mathrm{mg} / \mathrm{kg}$ body weight) in iron-intoxicated rats reduced the hepatic and renal histological changes induced by iron. This can be explained by the antioxidant and chelating ability of $\mathrm{HN}$, which significantly decreased the oxidative stress, resulting in reduction of pathological changes and restoration of normal cellular functions (Pari et al., 2015).

The immunohistochemical examination revealed that liver of DZN intoxicated group 
showed strong positive TNF- $\alpha$ immunoreactivity in the cytoplasm of hepatocytes compared to control group, indicating inflammatory effect of DZN. TNF- $\alpha$ is a key regulator of the immune and inflammatory processes and controls the expression of the inflammatory genes. So, the overproduction of TNF- $\alpha$ contributes significantly to the pathological consequences seen in many inflammatory diseases (Kowalski et al., 2001).

Over production of pro-inflammatory cytokines may share in manifestation of the systemic inflammatory response, developing organ failure (Kotb and Calandra, 2003). The increase TNF- $\alpha$ level coincided with those reported by Hariri et al. (2010), Ahmed et al. (2013), Pakzad et al. (2013) and Mehanny et al. (2015) that found serum level of TNF- $\alpha$ was increased significantly by diazinon. The literature reports a reciprocal relationship between oxidative stress and TNF- $\alpha$ expression, i.e., oxidative stress induces TNF- $\alpha$ expression and TNF- $\alpha$ increases oxidative stress (Fischer and Maier 2015 and Voltan et al., 2016).

Besides, DZN induces the expression of cyclooxygenase-II and NF- $\kappa \mathrm{B}$, which is upstream of TNF- $\alpha$ (Ogasawara et al., 2017 and Proskocil et al., 2019). Therefore, AbdelDaim et al. (2020) explained increased TNF- $\alpha$ expression in diazinon treated rats (20 $\mathrm{mg} / \mathrm{kg} /$ day for 4 weeks) by a direct influence of DZN intoxication or an indirect influence due to oxidative mechanism.

In the present study, co-administration of $\mathrm{HN}$ with DZN revealed weak positive TNF- $\alpha$ immuno-reactivity in the cytoplasm of hepatocytes compared to DZN alone, indicating anti-inflammatory effect of HN. These results were supported by Nathiya et al. (2016) who observed that $\mathrm{HN}$ treatment $(200 \mathrm{mg} / \mathrm{kg} /$ day for 50 days) decreased expression of TNF- $\alpha$ and $\mathrm{NF}-\kappa \mathrm{B}$ in liver of rats treated with antitubercular drugs as $\mathrm{HN}$ eliminated the oxidative stress by neutralizing the ROS which result in the inactivation of NF- $\kappa \mathrm{B}$ pathway and subsequently suppress the release of proinflammatory cytokines TNF- $\alpha$.
Moreover, HN displays an obvious protective impact against inflammatory disorders, both in vivo and in vitro, possibly through a mechanism including an inhibition of eicosanoid synthesis and/or antioxidant free radical scavenger activity (Rabee and Bennasir, 2018).

In addition, Aldossary

illustrated that treatment with $\mathrm{HN}$ (100 $\mathrm{mg} / \mathrm{kg} /$ day for 7 days) significantly impeded acute kidney injury induced by methotrexate as demonstrated by inhibition of inflammatory responses, and suppression of NF- $\mathrm{NB}$ pathway. Similarly, earlier researches related the nephroprotective effect of $\mathrm{HN}$ to downregulation of oxidative/nitrative stress, and inflammation (Siddiqi et al., 2015; Fouad and Al-Melhim, 2018 and Turk et al., 2018).

\section{Conclusions and recommendations}

In conclusion, the results of current study indicate that HN plays a protective role in reducing DZN-induced oxidative and inflammatory damage in liver which could be due to its antioxidant potential by scavenging the free radicals and restoration of hepatic enzymatic (SOD)\& non enzymatic (GSH) antioxidants and anti-inflammatory effects by a significant decrease in TNF- $\alpha$. Continuous monitoring of serum liver enzymes is recommended in DZN exposed workers for early detection of liver damage, beside further investigations on the mechanism of action of $\mathrm{HN}$ are needed to strengthen its future supplementation for those workers.

\section{Conflicts of interest}

There is no conflict of interest to declare.

\section{References}

Abdallah NM, Amien NE, Mohamed MR, Nada AS and Mohamed M A (2013): The Protective value of hesperidin in mitigating the biochemical perturbations and trace element alterations induced by acrylonitrile in rats. Egypt J Hosp Med; 52:599-607. 
Abdel-Daim MM, Abushouk AI, Alkhalf MI, Toraih EA, FawzyMS, Ijaz H, Aleya L and Bungau SG (2018): Antagonistic effects of Spirulina platensis on diazinon-induced hemato-biochemical alterations and oxidative stress in rats. Environ Sci Pollut Res Int; 25:27463-27470.

Abdel-Daim MM, Abushouk AI, Bahbah EI, Bungău SG, Alyousif MS, Aleya L, Alkahtani S (2020): Fucoidan protects against subacute diazinon-induced oxidative damage in cardiac, hepatic, and renal tissues. Environ Sci Pollut Res https://doi.org/10.1007/s11356-02007711-w.

Abdollahi M, Ranjbar A, Shadnia S, Nikfar $S$ and Rezaie A (2004): Pesticides and oxidative stress: a review. Med. Sci. Monit; 10: RA141-RA147.

Ahmadi A, Heidarian E, Ghatreh-Samani K (2019): Modulatory effects of artichoke (Cynara scolymus L.) leaf extract against oxidative stress and hepatic TNF-alpha gene expression in acute diazinon-induced liver injury in rats. J Basic Clin Physiol Pharmacol; 30:20180180.

Ahmed MA, Ahmed HI, and El-Morsy EM (2013): Melatonin protects against diazinoninduced neurobehavioral changes in rats. Neurochem Res; 38(10):2227-2236.

Al-Attar AM (2015): Effect of grape seed oil on diazinon-induced physiological and histopathological alterations in rats. Saudi J Biol Sci; 22(3): 284-292.

Aldossary SA (2019): Protective Effect of Hesperidin against Methotrexate-Induced Nephrotoxicity in Rats. Life Sci J;16(2):18-22.

Altuntas I, Kilinc I, Orhan H, Demirel R, Koylu H, Delibas N. (2004): The effects of diazinon on lipid peroxidation and antioxidant enzymes in erythrocytes in vitro. Hum Exp Toxicol;23:9-13.

doi:10.1191/0960327104ht408oa.

Amirkabirian N, Teimouri F, Esmaily H, Mohammadirad A, Aliahmadi $A$ and Abdollahi M (2007): Protection by pentoxifylline of diazinon-induced toxic stress in rat liver and muscle. Toxicol Mech
Methods; 17:215-21. doi:10.1080/15376510600943783.

Anandan R and Subramanian P (2012): Renal protective effect of hesperidin on gentamicin-induced acute nephrotoxicity in male Wistar albino rats. Redox Report; 17:5, 219-226,

DOI:

10.1179/1351000212Y.0000000019.

Bancroft ID and Cook HC (1994): Immunohistochemistry. In: Manual of Histological Techniques and Their Diagnostic Applications, Churchill Living Stone, Edinburgh, London, Madrid, Melbourne, New York and Tokyo. pp: 263.

Bancroft JD and Stevens A (1996): Theory and Practice o Histological Techniques. $\left(4^{\text {th }}\right.$ ed.). Churchill Livingstone, Edinburgh.

Beydilli H, Yilmaz N, Cetin ES, TY, Celik OI, Sahin C, Topal H, Cigerci IH and Sozen H (2015): Evaluation of the protective effect of silibinin against diazinon induced hepatotoxicity and free-radical damage in rat liver. Iran Red Crescent Med J; 17(4): e25310.

Bhan A (1995): Immunoperoxidase in: Diagnostic Immunopathology. ( $2^{\text {nd }}$ ed.). Raven Press Ltd, New York, pp: 711-715.

Cemek M, Buyukokurog lu ME, Yurumez Y, Yavuz Y, Aslan A, Buyukben A and Aymelek F (2010): Tissue trace and major element levels in organophosphate insecticide fenthion (Lebaycids) toxicity in rats: prophylactic and therapeutic effect of exogenous melatonin. Ecotoxicol Environ Saf; 73 (2), 206-212.

Çetin A, Çiftçi O and Otlu (2016): A Protective effect of hesperidin on oxidative and histological liver damage following carbon tetrachloride administration in Wistar rats. Arch Med Sci; 3: 486-493.

Danaei GH, Memar B, Ataee R and Karami $M$ (2019): Protective effect of thymoquinone, the main component of Nigella sativa, against diazinon cardio-toxicity in rats. Drug Chem Toxicol; 42:585-591.

El-Shenawy NS, El-Salmy F, Al-Eisa RA and El-Ahmary B (2010): Amelioratory effect of vitamin $\mathrm{E}$ on organophosphorus insecticide 
diazinon-induced oxidative stress in mice liver. Pestic Biochem Physiol; 96(2): 101-107.

Ezzi L, Haouas Z, Salah IB, Sakly A, Grissa I, Chakroun S, Kerkeni E, Hassine M, Mehdi $M$ and Cheikh HB (2016): Toxicopathic changes and genotoxic effects in liver of rat following exposure to diazinon. Environ Sci Pollut Res; 23:11163-11170.

Fischer $R$ and Maier $O$ (2015): Interrelation of oxidative stress and inflammation in neurodegenerative disease: role of TNF. Oxidative Med Cell Longev; 2015:610813. https://doi.org/10.1155/2015/610813.

Fouad AA and Al-Melhim WN (2018): Vanillin mitigates the adverse impact of cisplatin and methotrexate on rat kidneys. Hum Exp Toxicol; 37(9): 937-943.

Gokcimen, A.; Gulle, K.; Demirin, H.; Bayram, D.; Kocak, A. and Altuntas, I. (2006): Effects of diazinon at different doses on rat liver and pancreas tissues. Pestic Biochem Physiol, 87: 103-108.

Hariri AT, Moallem SA, Mahmoudi M, Memar B and Hosseinzadeh H (2010): Subacute effects of diazinon on biochemical indices and specific biomarkers in rats: Protective effects of crocin and safranal. Food Chem Toxicol; 48: 2803-2808.

Jafari M, Salehi M, Ahmadi S, Asgari A, Abasnezhad $M$ and Hajigholamali $M$ (2012): The role of oxidative stress in diazinon-induced tissues toxicity in Wistar and Norway rats. Toxicol Mech Methods; 22:638-47. doi:10.3109/15376516.2012.716090.

Kalender S, Ogutcu A, Uzunhisarcikli M, Açikgoz F, Durak D, Ulusoy Y and Kalender Y (2005): Diazinon-induced hepatotoxicity and protective effect of vitamin $E$ on some biochemical indices and ultrastructural changes. Toxicol; 211(3): 197-206.

Karimani A, Mamashkhani Y, Moghadam Jafari A, Akbarabadi $M$ and Heidarpour $M$ (2018): Captopril Attenuates diazinon-induced oxidative stress: a subchronic study in rats. Iran J Med Sci;43(5):514-522.
Kotb $M$ and Calandra T (2003): Cytokines and Chemokines in Infectious Diseases Handbook. New Jersey: Humana Press Totowa. Kowalski J, Blada P, Kucia K, Madej A and Herman ZS (2001): Neuroleptics normalize increased release of interleukin- 1 beta and tumor necrosis factor alpha from monocytes in schizophrenia. Schizophr Res, 50:169-175.

Lari P, Abnous K, Imenshahidi M, Rashedinia M, Razavi M and Hosseinzadeh H (2015): Evaluation of diazinon-induced hepatotoxicity and protective effects of crocin. Toxicol Ind Health; 31(4) 367-376.

Larkin DJ and Tjeerdema RS (2000): Fate and effects of diazinon. Rev Environ Contam Toxicol; 166:49-82.

Lee K-A, Lee S-H, Lee Y-J, Baeg S M and Shim J-H (2012): Hesperidin Induces Apoptosis by Inhibiting Sp1 and Its Regulatory Protein in MSTO-211H Cells, Biomol Ther (Seoul); 20(3): 273-279.

Li C and Schluesener H (2017): Healthpromoting effects of the citrus flavanone hesperidin. Crit Rev Food Sci Nutr; 57:613-31.

Mehanny PE, El Deeb SO, Tag El- Din HA, Sobhy HM, Mansour MK and Mahana NA (2015): Effects of curcumin on diazinoninduced biochemical and cytogenetical alterations in male rats. Egypt $\mathrm{J}$ Chem Environ Health; 1 (1):914-932.

Merzoug S and Toumi M (2017): Effects of hesperidin on formaldehyde-induced toxicity in pregnant rats. EXCLI J; 16: 400-413.

Mossaa A H, Swelamb ES and Mohafrasha SMM (2015): Sub-chronic exposure to fipronil induced oxidative stress, biochemical and histotopathological changes in the liver and kidney of male albino rats. Toxicol Rep; 2: 775-784.

Murray R. (1984): Aspartate aminotransferase. In: Clinical Chemistry. Kaplan, A. and Peace, AL. (eds.). The C.V. Mosby Co., St Louis, Toronto, Princeton,1112-1116.

Nagi MN, al-Bekairi AM and al-Sawaf HA (1995): Spectrophotometric assay for superoxide dismutase based on the nitrobluetetrazolium reduction by glucose- 
glucose oxidase. Biochem Mol Biol Int; 136(3):633-638.

Nathiya S, Rajaram $S$ and Abraham $P$ (2016): Hesperidin alleviates antitubercular drug induced oxidative stress, inflammation and apoptosis in rat liver. Int J Biomed Res; 7(7): 439-446.

Nemzek JA, Bolgos GL, Williams BA and Remick DG (2001): Differences in normal values for murine white blood cell counts and other hematological parameters based on sampling site. Inflamm. res; 50: 523-527.

Ogasawara N, Matsushima M, Kawamura N, Atsumi K, Yamaguchi T, Ochi H, Kusatsugu Y, Oyabu S, Hashimoto N, Hasegawa Y (2017): Modulation of immunological activity on macrophages induced by diazinon. Toxicol; 379:22-30.

Ohkawa H, Ohishi N and Yagi K (1979): Assay for lipid peroxides in animal tissues by thiobarbituric acid reaction. Anal Biochem; 95: 351- 358.

Pakzad M, Fouladdel S, Nili-Ahmadabadi A, Pourkhalili N, Baeeri M, Azizi E, Sabzevari O, Ostad SN and Abdollahi M (2013): Sublethal exposures of diazinon alters glucose homeostasis in Wistar rats: biochemical and molecular evidences of oxidative stress in adipose tissues. Pestic Biochem Physiol; 105:57-61.

Parhiz H, Roohbakhsh A, Soltani F, Rezaee $R$ and Iranshahi $M$ (2015): Antioxidant and anti-inflammatory properties of the citrus flavonoid's hesperidin and hesperidin: an updated review of their molecular mechanisms and experimental models. Phytother Res; 29 (3): 323-33RT1.

Pari L, Karthikeyan A, Karthika $P$ and Rathinam (2015): A Protective effect of hesperidin on oxidative stress, dyslipidemia and histological changes in iron-induced hepatic and renal toxicity in rats. Toxicol Rep; 2: 4655.

Peixoto F, Vicente $J$ and Madeira VMC (2004): A comparative study of plant and animal mitochondria exposed to paraquat reveals that hydrogen peroxide is not related to the observed toxicity. Toxicol In Vitro; 18: 733-739.

Proskocil BJ, Grodzki ACG, Jacoby DB, Lein PJ and Fryer AD (2019): Organophosphorus pesticides induce cytokine release from differentiated human THP1 cells. Am J Respir Cell Mol Biol; 61:620-630.

Rabee A A A and Bennasir HAH (2018): Hesperidin an antioxidant flavonoid prevents carbon tetrachloride-induced hepatic toxicity in male albino rats. JIPBS; 5 (4): 127-132.

Rahman I (2005): The role of oxidative stress in the pathogenesis of COPD: implications for therapy Treat Respir Med; 4: 175-200.

Reitman S and Frankel S (1957): A colometric method for the determination of serum glutamic oxalacetic and glutamic pyruvic transaminases. Am J Clin Pathol; 28: 56-63.

Sarabia L, Maurer I and Bustos-Obrego'n E (2009): Melatonin prevents damage elicited by the organophosphorus pesticide diazinon on the mouse testis. Ecotoxicol Environ Safety; 72: 663-668.

Sarhan OMM and Al-Sahhaf ZY (2011): Histological and biochemical effects of diazinon on liver and kidney of rabbits. Life Sci J; 8 (4):1183-1189.

Shah MD and Iqbal M (2010): Diazinoninduced oxidative stress and renal dysfunction in rats. Food Chem Toxicol; 48(12): 33453353.

Shaik IH and Mahvar R (2006): Rapid determination of reduced and oxidized glutathione levels using a new thiol-masking reagent and the enzymatic recycling method: application to the rat liver and bile samples. Anal Bioanal Chem; 385(1):105-113. https://doi.org/10.1007/s00216-006-0375-8

Sharma $D$ and Sangha GK (2014): Triazophos induced oxidative stress and histomorphological changes in liver and kidney of female albino rats. Pestic Biochem Physiol; 110: 71-80.

Siddiqi A, Nafees S, Rashid S, Sultana S and Saidullah B (2015): Hesperidin ameliorates trichloroethylene-induced nephrotoxicity by 
abrogation of oxidative stress and apoptosis in wistar rats. Mol Cell Biochem; 406:9-20.

Slotkin TA, Skavicus S, Ko A, Levin ED and Seidler FJ (2019): Perinatal diazinon exposure compromises the development of acetylcholine and serotonin systems. Toxicology; 424:152240.

https://doi.org/10.1016/j.tox.2019.152240

Tirkey N, Pilkhwal S, Kuhad A and Chopra K (2005): Hesperidin, a citrus bioflavonoid, decreases the oxidative stress produced by carbon tetrachloride in rat liver and kidney BMC Pharmacol;5:2 doi:10.1186/1471-2210-52.

Turk E, Kandemir FM, Yildirim S, Caglayan C, Kucukler $S$ and Kuzu $M$ (2018): Protective effect of hesperidin on sodium arsenite-induced nephrotoxicity and hepatotoxicity in rats. Biol Trace Elem Res; doi: 10.1007/s12011-018-1443-6.

Voltan R, Secchiero P, Casciano F, Milani D, Zauli $G$ and Tisato V (2016): Redox signaling and oxidative stress: cross talk with TNFrelated apoptosis inducing ligand activity. Int $\mathbf{J}$ Biochem Cell Biol; 81:364-374.

Wang D, Singhasemanon $\mathbf{N}$ and Goh KS (2017): A review of diazinon use, contamination in surface waters, and regulatory actions in California across water years 19922014. Environ Monit Assess; 189:310.

Yousefizadeh S, Farkhondeh $\mathbf{T}$ and Samarghandian S (2019): Age-related diazinon toxicity impact on blood glucose, lipid profile and selected biochemical indices in male rats. Curr Aging Sci; 12, 49-54. 


\section{هيسبيريدين: طريقة جديدة لتحسين السمية الكبدية التي يسببها الديازينون فى ذكور الجرذان}

\section{البيضاء البالغة}

داليا إبراهيم أحمد مسلم ، مني عاطف

قسم الطب الثرعي و السموم الاكلينيكية ـ كلية الطب البشري -جامعة الزقازيق

الملخص العربي

يعد الديازينون من المبيدات الحشرية الفوسفورية العضوية الأكثر استخدامًا في مكافحة الآفات الزراعية ، مما يزيد من فرص التعرض لهذه المركبات التي قد يكون لها آثار جانبية ضارة. ويعد الهيسبيريدين من مجموعة البيوفلافونويد التي لها العديد من التأثيرات المضادة للالتهابات وكذلك تعد من مضادات الأكسدة. وأجريت هذه الدراسة لتقييم الدور الوقائي لعقار الهيسبيريدين ضد هن الاثار السامة للايازينون علي كبد ذكور الجرذان البيضاء البالغة.

أجري هذا البحث علي ^ء جرذ ذكر أبيض بالغ مقسمة الي أربع مجموعات كما يلي؛ المجموعة الأولى ضابطة (IA و IB و ، المجمو عة الثانية : تم اعطاء الجرذان الهيسبيريدين ( •0 مجم / كجم) ، المجموعة الثالثة: تم اعطاء الجرذان ديازينون (• (IC / كجم) و المجموعة الر ابعة : تم اعطاء الجرذان هسبريدين وديازينون بنفس الجرعات السابقًة. نم إعطاء العلاج بواسطة انبوب عن طريق الفم مرة واحدة يوميا لمدة 7 أسابيع. وقد تم الحصول علي عينات الدم لتقييم إنزيمات الكبد في الدم. وقد تم الحصول علي عينات من الكبد لتحديد مستوي المالون داي الدهيد ،و مضادات الاكسدة (انزيم السوبر اوكسيد ديسميوتاز وانزيم الجلوناثيون) ، كما تم فحص الكبد بو اسطة الميكروسكوب الضوئي وعمل در اسة نسيجية كيميائية مناعية بو اسطة عامل نخر الورم- ألفا. أثتتت هذة الدر اسة ان للايازينون تأثثير ات سامة علي الكبد و التي قد اتضحت من خلال زيادات كبيرة ذات دلالات إحصائية في مستوي الإنزيمات الكبدية وكذلك في مستوي المالون داي الدهيد بالكبد و إنخفاض ذى دلالة إحصائية في مستوى نشاط مضادات الأكسدة بالدم. وقد تأكدت هذه النتائج بالتغييرات الهستوباثولوجية بالكبد مع ظهور اللون البنى الناتج عن التفاعل الهستوكيميائى لعامل نخر الورم- ألفا بكثافة فى سيتوبلازم خلايا الكبد.كما تبين أن إعطاء عقار الهيسبيريدين مع الديازينون يؤدي إلي تحسن جزئي لهذه التأثير ات السامة علي أنسجة الكبد. والخلاصة: أن الهيسبيريدين له آثار وقائية ضد الآثار السمية للايازينون التي يسبيها في كبد الجرذان البيضاء البالغة. 